\title{
ECHO 9 VIRUS INFECTION AND CONGENITAL
}

\section{MALFORMATIONS}

\author{
BY \\ JOAN B. LANDSMAN, N. R. GRIST, AND CONSTANCE A. C. ROSS \\ University Departments of Infectious Diseases and Viral Epidemiology, Ruchill Hospital, Glasgow
}

The properties of enteroviruses justify their consideration as possible causes of foetal damage: they are highly prevalent and cause infections which, although usually of minor severity, are often associated with viraemia. Of the enteroviruses, ECHO type 9 is of particular interest because of its periodic epidemic prevalence and the similarity to rubella of many of the infections it causes. Studies by Rantasalo, Penttinen, Saxén, and Ojala (1960) and by Kleinman, Prince, Mathey, Rosenfield, Bearman, and Syverton (1962) did not reveal unequivocal evidence of association between ECHO 9 virus infection during pregnancy and malformation of the infant born subsequently. The possibility that this infection may not cause foetal damage is also of importance to the clinician assessing the implications of a rubelliform illness during pregnancy, and to the epidemiologist evaluating the risk of congenital abnormality complicating "rubella" in studies in which an unknown proportion of maternal illnesses might have been due to ECHO 9 infection with fever, rash, and lymph-node enlargement. An epidemic of ECHO 9 infection in Glasgow in 1960 (Landsman and Bell, 1962; Combined Scottish Study, 1964) provided an opportunity to investigate the possible association of maternal infection with foetal damage.

\section{Material and Methods}

\section{Serum Specimens}

Single specimens of serum were obtained from all women at their first attendance at certain ante-natal clinics in Glasgow. The clinics were those at The Royal Maternity and Stobhill Hospitals and all those run by the Corporation of Glasgow's Maternity and Child Welfare Department. Most of the women attending the clinics were domiciled in Glasgow, but a number of those attending the hospital clinics came from outside the city. The serum specimens consisted of residual serum, adequate for antibody tests, after routine Wassermann or Kahn tests, etc., had been completed in the laboratories associated with the ante-natal clinics. Specimens from women who were $\mathrm{Rh}$ negative were not forwarded from the Corporation laboratory, but were available from the two hospital laboratories. Some 441 sera submitted were not included in this analysis because:

(1) They were insufficient in quantity or were anticomplementary and so were unsuitable for ECHO 9 antibody tests (350);

(2) The outcome of pregnancy could not be traced because of change of address, or because the mother lived in areas beyond the city boundary, etc. (78);

(3) Diagnosis of pregnancy not sustained (13).

\section{RECORDS}

Women were traced by means of laboratory specimen numbers, using a pre-arranged code which indicated the clinic attended. Ante-natal records were examined on the clinic premises and the desired information was transcribed onto punch cards. These records were those used in the normal conduct of the clinics. Questions regarding illness during pregnancy were not specifically directed towards possible ECHO 9 infection. None of the women was interviewed by us.

Among the details entered on punch cards were the mother's age and parity, the date on which serum was obtained, and the duration of pregnancy at that date (calculated in weeks from the date of onset of the last menstrual period). For those attending the hospital clinics, details of each confinement were obtained from the obstetric units concerned. For those attending the Corporation clinics, the appropriate entry on the ante-natal 
record reporting the result of pregnancy was consulted. Information about patients confined at home or in private accommodation was sought from the general practitioner, whose name and address were obtained from the ante-natal record.

Details of the sex and birth weight of infants were not always obtained for those born outside hospital, but when available were entered on the mother's punch card along with the birth date and any comment on congenital defect or other abnormal condition of the infant recognized at birth. With the help of the city's health visitors a follow-up after one year was carried out on most of the infants whose mothers' blood serum had been obtained within the first 16 weeks of pregnancy, and on a sample of the others.

For the purpose of the follow-up the proforma used was that prepared by the Public Health Laboratory Service of England and Wales for its investigation of infections in early pregnancy. Our records of women whose first serum specimen was obtained within the first 16 weeks of pregnancy were made available to Dr J. C. McDonald, Director of the Epidemiological Research Laboratory, Colindale, London, for inclusion in the PHLS investigation, and the congenital defects recorded were those listed in Appendix B of the instructions issued in connexion with that survey.

\section{LABORATORY MethodS}

Examination for ECHO 9 antibodies was carried out by complement-fixation (CF) technique, using an antigen prepared from human amnion tissue culture infected with a current epidemic strain of ECHO 9 virus; the details of the method have been described elsewhere (Bell, Stott, and Ross, 1964). The serological titres for ECHO 9 antibodies were expressed as reciprocals; a titre of $1: 128$ or greater was regarded as indicative of recent infection (Bell and others, 1964), and titres of $1: 32$ or $1: 64$ as presumptive evidence of recent infection.

\section{RESULTS}

Between October, 1960, and February, 1961, single specimens of serum were obtained from 2,631 pregnant women. Of these pregnancies, 41 resulted in abortion, 48 in a stillbirth (11 with a congenital defect), and 2,542 in a live birth (45 with a congenital defect).

Table I shows the distribution of the 2,631 pregnancies by month of conception correlated with evidence of the activity of ECHO 9 virus in Glasgow shown by 77 isolations of this virus from patients, mostly with aseptic meningitis or febrile exanthem.
It can be seen that almost all of the women had a possibility of exposure to ECHO 9 virus during the early months of pregnancy. ECHO $9 \mathrm{CF}$ antibody titres of $1: 128$ or more were found in $31(1 \cdot 2$ per cent.) and titres of $1: 32$ to $1: 64$ in $256(9 \cdot 8$ per cent.). However, it was not possible to determine from the available evidence whether the infections occurred during or before pregnancy.

TABLE I

DISTRIBUTION OF 2.631 PREGNANCIES BY MONTH OF CONCEPTION AND OF ISOLATIONS OF ECHO 9 VIRUS IN GLASGOW

\begin{tabular}{|c|c|c|c|}
\hline \multirow{2}{*}{$\begin{array}{l}\text { Month } \\
\text { (1960) }\end{array}$} & \multicolumn{2}{|c|}{$\begin{array}{c}\text { Pregnancies } \\
\text { (by month of conception) }\end{array}$} & \multirow{2}{*}{$\begin{array}{l}\text { Isolations of } \\
\text { ECHO } 9 \text { Virus } \\
\text { (in Glasgow) }\end{array}$} \\
\hline & Total & $\begin{array}{l}\text { With ECHO } 9 \\
\text { Antibody Titres } \\
\text { of } 1: 32 \text { or More }\end{array}$ & \\
\hline 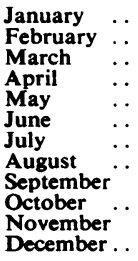 & $\begin{array}{r}2 \\
39 \\
136 \\
209 \\
337 \\
415 \\
467 \\
404 \\
294 \\
196 \\
96 \\
36\end{array}$ & $\begin{array}{r}0 \\
4 \\
8 \\
13 \\
36 \\
38 \\
57 \\
48 \\
35 \\
31 \\
11 \\
6\end{array}$ & $\begin{array}{r}0 \\
0 \\
0 \\
0 \\
1 \\
8 \\
28 \\
18 \\
14 \\
7 \\
0 \\
1\end{array}$ \\
\hline Total & 2,631 & 287 & 77 \\
\hline
\end{tabular}

Congenital Defects. - 56 were reported, of which 47 were recognized at birth and nine by the time of follow-up at one year. Table II shows the outcome of pregnancy in relation to the titre of ECHO 9 antibody. The proportion of pregnancies resulting in a congenital defect was the same $(2 \cdot 1$ per cent.) among mothers with significant titres of antibody as among those without such antibody. Abortions occurred with similar frequency in those with and those without significant titres. Thus no evidence was obtained that recent ECHO 9 infection was associated with increased foetal loss or damage.

TABLE II

OUTCOME OF 2,631 PREGNANCIES RELATED TO TITRE OF ECHO 9 ANTIBODY

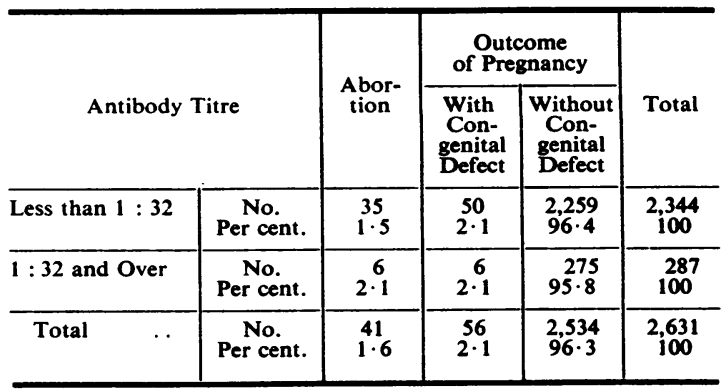


Comparison of the normal with the congenitally defective group, taking into consideration the duration of pregnancy at which the examination for antibodies was made, provides the figures shown in Table III. In 67 of the 592 pregnancies in which antibody estimations were made within the first 16 weeks, a titre of ECHO 9 antibody of $1: 32$ or more was recorded. Two malformed infants were found in this group of 67 , an incidence of 3 per cent. The 1,998 pregnancies of 17 weeks' duration or more at the time of examination included 214 in which the antibody titre was at least $1: 32$. Four malformed infants were identified, an incidence of 1.9 per cent.

TABLE III

COMPARISONOF 2,590 VIABLE PREGNANCIES ACCORDING TO DURATION OF GESTATION AT TIME OF EXAMINATION FOR TITRE OF ECHO 9 ANTIBODY

\begin{tabular}{|c|c|c|c|c|c|}
\hline \multirow{2}{*}{$\begin{array}{c}\text { Dura- } \\
\text { tion } \\
\text { of preg- } \\
\text { nancy } \\
\text { (wks) }\end{array}$} & \multirow{2}{*}{ Antibody Titre } & \multicolumn{2}{|c|}{$\begin{array}{l}\text { Outcome of } \\
\text { Pregnancy }\end{array}$} & \multirow{2}{*}{ Total } & \multirow{2}{*}{$\begin{array}{c}\text { Per cent. } \\
\text { Defec- } \\
\text { tive }\end{array}$} \\
\hline & & $\begin{array}{c}\text { Without } \\
\text { Con- } \\
\text { genital } \\
\text { Defect }\end{array}$ & $\begin{array}{l}\text { With } \\
\text { Con- } \\
\text { genital } \\
\text { Defect }\end{array}$ & & \\
\hline$\overline{\text { Up to } 16}$ & $\begin{array}{l}\text { Less than } 1: 32 \\
1: 32 \text { or More }\end{array}$ & 11 & $\begin{array}{r}514 \\
65\end{array}$ & $\begin{array}{r}525 \\
67\end{array}$ & $\begin{array}{l}2 \cdot 1 \\
3 \cdot 0\end{array}$ \\
\hline $\begin{array}{l}17 \text { or } \\
\text { More }\end{array}$ & $\begin{array}{l}\text { Less than } 1: 32 \\
1: 32 \text { or More }\end{array}$ & $\begin{array}{r}39 \\
4\end{array}$ & $\begin{array}{r}1,745 \\
210\end{array}$ & $\begin{array}{r}1,784 \\
214\end{array}$ & $\begin{array}{l}2 \cdot 2 \\
1 \cdot 9\end{array}$ \\
\hline Total & & 56 & 2,534 & 2,590 & $2 \cdot 2$ \\
\hline
\end{tabular}

Thus pregnancies in which infection was shown to have occurred before the end of the 16th week were not associated with a higher rate of congenital defects than those in which the examination was not made until the 17 th week or later.

TYPES OF MALFormation.-Deformities involving the central nervous system were found in thirteen live born infants and in eleven of the 49 stillbirths; the most frequent abnormality was anencephalus, present in two live born and ten stillborn infants. The mother of one of these had a titre of ECHO 9 antibody of $1: 32$, as had the mother of one of the eleven infants with skeletal deformities. In the group of eight defects of the cardiovascular system, the mother of an infant with a bilocular heart who died at 72 hours also showed evidence of infection with ECHO 9 virus. This was the only mother of a malformed child who gave a history of febrile illness early in pregnancy. She reported having had "influenza" at the 9th to 10th week, i.e. about October, 1960. Proof of this was not sought in her serum sample obtained at the 23rd week, but influenza was not prevalent in the city at that time.

Illness DURING Pregnancy.-Seven mothers reported a febrile respiratory illness during pregnancy; details regarding these pregnancies are given in Table IV.

One other mother, exposed in March, 1961, at about the 18th week of her 5th pregnancy to rubella in her other children, remained well. The infant appeared normal at birth, but at 1 year was reported to be spastic and mentally retarded, with hydrocephaly.

\section{Discussion}

In the present investigation presumptive evidence of ECHO 9 virus infection during pregnancy was based on the serological demonstration of a CF antibody titre of at least $1: 32$. The CF test was employed in preference to the neutralization test because it has been shown that CF antibodies to ECHO 9 virus develop more slowly and disappear more rapidly than neutralizing antibodies-although

TABLE IV

OUTCOME OF SEVEN PREGNANCIES DURING WHICH THERE WAS A REPORTED FEBRILE ILLNESS

\begin{tabular}{|c|c|c|c|c|c|c|c|}
\hline \multirow{2}{*}{$\begin{array}{l}\text { Patient } \\
\text { No. }\end{array}$} & \multirow{2}{*}{$\begin{array}{l}\text { Month } \\
\text { of } \\
\text { Illness }\end{array}$} & \multirow{2}{*}{$\begin{array}{c}\text { Clinical } \\
\text { Description }\end{array}$} & \multicolumn{2}{|c|}{ Gestation (wks) } & \multirow{2}{*}{$\begin{array}{c}\text { Antibody } \\
\text { Titre }\end{array}$} & \multirow[b]{2}{*}{ Outcome } & \multirow[b]{2}{*}{ Follow-up } \\
\hline & & & At Illness & $\begin{array}{c}\text { At Serological } \\
\text { Examination }\end{array}$ & & & \\
\hline 1 & August (1960) & Fever and cough & $3-4$ & 19 & $<1: 8$ & $\begin{array}{l}\text { Normal but } \\
\text { premature }\end{array}$ & No \\
\hline 2 & October & $\begin{array}{c}\text { "Heavy cold" in } \\
\text { hospital } \\
3-4 \text { days }\end{array}$ & $4-6$ & 18 & $1: 8$ & Normal & Yes \\
\hline 3 & October & "Influenza" & $9-10$ & 23 & $1: 32$ & $\begin{array}{l}\text { Bilocular heart } \\
\text { (died at } 3 \text { days) }\end{array}$ & $\begin{array}{c}\text { Not } \\
\text { applicable }\end{array}$ \\
\hline 4 & October & "Influenza" & 11 & 12 & $<1: 8$ & Normal & Yes \\
\hline 5 & November & "Influenza" & 13 & 15 & $1: 8$ & Normal & Removed \\
\hline 6 & November & "Influenza" & 24 & 36 & $1: 8$ & Normal twins & Not traced \\
\hline 7 & February (1961) & Rubella & 19 & 13 & $1: 32$ & Normal & No \\
\hline
\end{tabular}


even CF titres may remain high for several months after infection (Bell and others, 1964). In addition, $\mathrm{CF}$ tests are much less expensive in time and materials than neutralization tests, and are therefore more practical for large-scale surveys such as the present. The main disadvantage of CF tests for ECHO 9 infection is that infections with other enteroviruses may give rise to heterotypic CF cross-reactions to ECHO 9 (Tyrrell, Clarke, Heath, and Curran, 1958; Johnsson, Böttiger, and Löfdahl, 1958; Wigand and Sabin, 1962). However, during the period of our study, ECHO 9 was the only epidemic enterovirus in the community and therefore it seemed reasonable to accept high antibody titres as presumptive evidence of recent infection with this virus. The highest titre associated with congenital abnormalities in our study was $1: 32$. Although lower than the titres usually found after overt illness associated with ECHO 9 virus infection (Bell and others, 1964), this level was selected to divide the mothers into two groups for comparison.

Our investigation, like that of Rantasalo and others (1960), shows no correlation between congenital malformations and presumptive serological evidence of ECHO 9 virus infection of mothers during pregnancy. The findings of Kleinman and others (1962) were similar, except for a suggestive association of skin abnormalities with ECHO 9 virus infection. The City of Glasgow's statistics also showed no significant increase of congenital malformations after the ECHO 9 epidemic of 1960, but ECHO 9 virus may not be more likely to cause foetal damage than other enteroviruses prevalent in other years.

It is possible that some congenital malformations were not recorded in the reports at our disposal, that some were missed because only a sample of infants was followed up at one year, and that others did not become apparent until later. It seems unlikely, however, that anencephalus would not be recorded, since this is an easily recognized malformation and notifications should therefore be accurate. Record (1961), using the Scottish statistics, showed that the contribution of anencephalus to stillbirths increased from 5.8 to 12.7 per cent. between 1938-41 and 1956-58, despite a reduction in the stillbirth rate from $41 \cdot 3$ to $23 \cdot 5$ per 1,000 total births during the same period. In his study of this malformation, he reported wide fluctuations in incidence with season, regardless of parity and social class, both of which show an association with anencephalus. This seasonal fluctuation suggested that infection with some neurotropic virus might cause this type of malformation, although other findings were against an infective cause.
Since the neurotropic properties of ECHO 9 virus are well established, its investigation as a possible teratogenic agent in regard to anencephalus was fully justified. In the present study twelve anencephalic births were registered, giving a rate of 24.5 per cent. among the 49 stillbirths. This is higher than the figure for the later years of Record's analysis but less than half the rate ( 58 per cent.) reported by Kleinman and his colleagues.

The negative nature of our report confirms the conclusions of others that, if ECHO 9 is a teratogenic agent, it is not markedly so. However, other viruses may yet be incriminated by observations whenever their epidemic prevalence is recognized. The introduction by the Ministry of 'Health (1963) of a scheme for notifying congenital malformations will be of great assistance to future investigations of this important problem.

\section{Summary}

Single specimens of serum from 2,631 women who became pregnant during an epidemic of ECHO type 9 virus infection were examined for complementfixing antibody to the virus.

The proportion of pregnancies resulting in a congenital defect was the same $(2 \cdot 1$ per cent.) among the 287 women with significant titres of antibody as among those $(2,344)$ without such antibody.

Pregnancies in which infection was shown to have occurred before the end of the 16th week were not associated with a higher rate of congenital defects.

56 congenital malformations were recorded at birth or at follow-up of a sample of the children at one year. Three of the 56 mothers had significant titres of antibody and one of these was the only mother of a malformed child to give a history of febrile illness in early pregnancy.

The study failed to show any correlation between congenital malformations and presumptive serological evidence of ECHO 9 virus infection of mothers during pregnancy.

We are grateful to all who helped in our investigations, particularly to Dr Nora Wattie, Principal Medical Officer, Maternity and Child Welfare Department, her medical colleagues, the Health Visitors, and the secretarial assistants in the city's ante-natal clinics. We thank Prof. D. F. Anderson, Prof. I. Donald, and Dr J. Hewitt at the Royal Maternity Hospital, and Dr D. McKay Hart at Stobhill Hospital for allowing us access to their records, and the records officers of the various units for their co-operation. We are indebted to Dr Telford Govan at the Royal Maternity Hospital, Dr J. Stevenson at Stobhill Hospital, and Dr Jean L. Young at the Corporation of Glasgow Laboratory for forwarding serum 
specimens. Mrs C. Rutter and Mr S. McMichael, A.I.M.L.T., assisted with the complement-fixation tests. Deep-freeze storage accommodation was provided by a grant from the Polio Research Fund.

\section{REFERENCES}

Bell, E. J., Stott, J., and Ross, C. A. C. (1964). Arch. ges. Virusforsch., 14, 147.

"Combined Scottish Study, Aseptic Meningitis in 1960: Mumps and ECHO 9 Virus Infections" (1964). Scot. med. J., 9, 141.

“Congenital Malformations" (1963). Standing Medical Advisory Committee for the Central Health Services
Council and the Minister of Health. Ministry of Health, London.

Johnsson, Y., Böttiger, M., and Löfdahl, A. (1958). Arch. ges. Virusforsch., 8, 306.

Kleinman, H., Prince, J. T., Mathey, W. E., Rosenfield, A. B., Bearman, J. E., and Syverton, J. T. (1962). Pediatrics, 29, 261.

Landsman, J. B. and Bell, E. J. (1962). Brit. med.J., 1, 12. Rantasalo, I., Penttinen, K., Saxén, L., and Ojala, A. (1960). Ann. Paediat. Fenn., 6, 175.

Record, R. G. (1961). Brit.J.prev. soc. Med., 15, 93.

Tyrrell, D. A. J., Clarke, S. K. R., Heath, R. B., and Curran, R. C. (1958). Brit.J. exp. Path., 39, 178.

Wigand, R. and Sabin, A. B. (1962). Arch. ges. Virusforsch., 11, 683. 